\title{
“CHUTA QUE É MACUMBA”: O PERCURSO HISTÓRICO-LEGAL DA PERSEGUIÇÃO ÀS RELIGIÕES AFRO-BRASILEIRAS
}

João Ferreira Dias ${ }^{1}$

\begin{abstract}
Resumo:
Neste artigo é analisado o percurso histórico-legal da perseguição às religiões afrobrasileiras, desde o seu começo até aos dias de hoje. Esse cenário de perseguição evidencia a forma como o aparelho jurídico brasileiro fez respaldo de concepções científicas raciais reproduzidas ao longo da história do comércio escravocrata e da constituição da República brasileira. Noções de "poluição social", "crendice", entre outras, continuam uma leitura científica evolucionista das culturas africanas, leitura instrumentalizada em favor da construção de um modelo de sociedade brasileira de base cristã. Esse fenómeno impõe-se, novamente, nos dias de hoje, de forma aguda com o cenário da perseguição religiosa evangélica, sendo que o sacrifício animal como modus operandi é utilizado como recurso político demonizatório.
\end{abstract}

Palavras-chave: religiões afro-brasileiras, perseguição, sacrifícios animais, lei.

\begin{abstract}
:
Stablished in colonial and slaver Brazil, afro-Brazilian religions, from the very beginning, have been persecuted and subjected to bias, facing racist theories and a social-politic rejection, deeply embodied in the Brazilian Constitution. Notions like "social pollution", "popular belief", among other, prevailed a scientific evolutionist disposition on African cultures, which was and still is used on the behalf of a Christian-based society. Those dispositions last until the present day, in a context of an emergent and intense evangelic war and are enforced by the Candomble ritual sacrifices as modus operandi, which tend to be invoked as 'prove' of its demoniacal background.
\end{abstract}

Keywords: Afro-Brazilian religions, persecution, animal sacrifices, law.

\section{DO VENTRE DA ÁFRICA À PARTEIRA BAIANA}

Relembrando Stuart Hall (2003), há que ter presente que foi o «turbilhão colonial» que produziu a África diaspórica, uma África que nas palavras do autor "passa bem”. Para que essa África, então, "passe bem”, ou seja, para que tenha sabido sobreviver na diáspora, foi necessário um longo processo de adaptação criativa, de capacidade de, perante as adversidades, ressignificar e reconfigurar os elementos constitutivos das múltiplas identidades africanas jogadas ao comércio escravocrata. A história da escravatura das Áfricas para o Brasil (Klein \& Luna 2009) e demais

1 Doutorado em Estudos Africanos pelo ISCTE-Instituto Universitário de Lisboa, e Mestre em História e Cultura das Religiões pela Faculdade de Letras da Universidade de Lisboa. É investigador Integrado ao Centro de Estudos Internacionais do ISCTE-Instituto Universitário de Lisboa, e Investigador Associado ao Centro de História da Faculdade de Letras da Universidade de Lisboa. Sítio pessoal: www.joaoferreiradias.net 
américas (Bergad, 2007) é longa. Segundo diversos autores, é na primeira metade do séc. XVI que se importa, pela primeira vez, escravos da África para o Brasil, a fim de trabalharem nas plantações. Todavia, seria com o séc. XVII que o comércio de escravos se iria agudizar, atingindo o seu apogeu até ao início do séc. XVIII, arrancando de África perto de dois milhões de escravos.

Contudo, ao contrário de uma certa disposição da história não-especializada, as relações estabelecidas no contexto escravocrata não eram unidirecionais nem passivas, apesar do binómio dominador/dominado ser a base da lógica social da escravatura. João José Reis (1988) defende momentos de negociação entre senhores e escravos. A vida de determinados escravos valorizados na memória coletiva afro-brasileira reporta esse lado bilateral e a liberdade crescente, a partir de finais do séc. XVIII. A vida de Manoel Joaquim Ricardo (Reis, 2016), o escravo rico, ou de Francisca da Silva (Castillo \& Parés 2007), José Pedro Autran (Parés \& Castillo 2015), ou Rodolpho Martins de Andrade (Castillo 2016), figuras importantíssimas na constituição do Candomblé baiano-nagô, são exemplos paradigmáticos da forma como os escravos e ex-escravos se articulavam no comércio transatlântico de modo a promover a sua mobilidade social e a subsistência económica, articulandose, simultaneamente, no cenário religioso. A biografia de José Pedro Autran e a forma como o seu regresso a África, como parte de um processo de deportação política, após a Revolta dos Malês ocorrida na Bahia oitocentista, alterou a estruturação social e religiosa na região de Ajudá, mostranos a dinâmica do processo escravocrata para além da ação central da exploração e violência física e emocional dos escravos, coisificados durante o período escravista (Parés \& Castillo, 2015).

Este cenário de circulações atlânticas, foi crucial para o estabelecimento de um conjunto de princípios religiosos africanos no Brasil. Ainda antes da formação do Candomblé, o ventre africano pariu no Brasil o chamado «calundu colonial». De terminologia quimbundo - de acordo com James H. Sweet (2003, p.144) calundu é uma corruptela do termo quimbundo quilundo -, o Calundu referia-se, lato senso, a práticas africanas ocorridas na região baiana, durante o séc. XVII até meados do séc. XVIII (Yeda Pessoa de Castro, 2001), altura em que foi substituído por um novo termo emergente: Candomblé. As formas multiversas pelas quais o Calundu se manifestava, expressava a busca continuada africana por uma existência religiosa e social capaz de reconstituir, nos moldes mínimos, a pátria abandonada. Inicialmente marcado por uma feição doméstica, em torno das práticas de cura hibridadas com congéneres indígenas, o Calundu foi conquistando espaço social, alargando a sua clientela a populações não-africanas, conseguindo, assim, não apenas renda, mas alguma proteção contra as proibições de que as práticas africanas eram objeto. De um formato 
doméstico, o Calundu foi-se, paulatinamente, alargando a um modelo conventual, com práticas iniciáticas e um corpo sacerdotal. De acordo o que se vem sabendo sobre os primeiros anos do Candomblé (Silveira 2006, Parés 2006, Castillo op. cit.), compreende-se que lidamos não apenas com um processo de continuas fundações, mas igualmente com um cenário em que cultos domésticos e públicos se sobrepõem. Os primeiros anos do designado "Candomblé da Barroquinha» (Silveira, 2006), i.e., os primórdios do culto instalados no bairro junto à Igreja da Barroquinha, em Salvador, são marcados pela existência de calundus domésticos e candomblés organizados, ou, se quisermos, candomblés domésticos e calundus organizados. Reproduzem-se, portanto, estruturações africanas autóctones yorùbá ${ }^{2}$ e daomeanas ${ }^{3}$, ao mesmo tempo que se dão inovações com vista à acomodação a um novo contexto sociocultural. Acompanhando as inovações religiosas, seguem as acomodações étnicas. As referências étnicas dos escravos eram diversas, conjugando dados prestados pelos próprios africanos, referências dos comerciantes de escravos sobre o local de embarque e/ou de captura, e denominações abrangentes do sistema escravista em solo brasileiro. Isto significa que o escravo teria a sua identidade étnica própria e autorreconhecida, a designação étnica registada pelo comerciante de escravos e a denominação simbólica do sistema colonial, a que Parés (2006) dá o nome de metaetnicidades.

A historiografia vem mostrando como o Candomblé foi sendo estruturado e fundado em etapas e momento justapostos. Contributo essencial para essas novas conclusões são, precisamente, as biografias dos agentes religiosos mencionados e de outros com trajetórias similares. As próprias irmandades católicas ${ }^{4}$, que pretendiam servir de locais de conversão ao catolicismo, desempenharam um importante papel no processo, ao agruparem os negros por origens étnicas - a fim de combaterem a circulação e o possível levante de escravos - permitiram que as afinidades étnicas promovessem o redesenhar das estruturas culturais e religiosas nativas, já que muito se assemelhavam às egbẹ (ebé), sociedades/confrarias religiosas yorùbá. Nesse contexto, o sincretismo afro-católico ganhou enorme significado, permitindo a sobrevivência étnica africana, a sobrevivência dos cultos africanos e, com as irmandades católicas, um sistema de compra de alforrias e de uma experiência organizada essencial para o estabelecimento dos primeiros templos ("terreiros") de Candomblé, verdadeiramente estruturados, como o Bogun de tradição daomeana, ou

2 Diz respeito a um conjunto de povos falantes de uma mesma língua, com variações regionais, que se reconhecem a si mesmo como povo (Peel, 2000; Matory, 2005; Ferreira Dias, 2011), geograficamente localizados em parte da Nigéria, Togo, República do Benim e Gana).

3 Atual República do Benim. Sobre a influência jeje-damoneana na formação do Candomblé ver Parés (2006).

4 Sobre irmandades católicas negras ver Reis (1996), Levi (2006), Couto (2014), et. al. 
os de feição yorùbá-nagô Casa Branca do Engenho Velho (Ilé Àṣẹ İyánásò Oká), Gantois (Ilé İyá Omi Àṣe İyámasé) e Alaketo, todos na viragem da primeira para a segunda metade do séc. XIX, depois do encerramento do Candomblé da Barroquinha, por necessidades de segurança, transladados os altares e comunidades para o Engenho Velho da Federação, na altura uma densa mata atlântica. Durante esse período, que vai das últimas décadas de 1700 até à primeira metade de 1900, inúmeros arranjos rituais tiveram lugar, respondendo a um processo de integração de divindades e seus povos. Processos iniciáticos, modelos de instituição de altares, ordenação hierárquica, procedimentos litúrgicos, constam-se dos vários elementos reordenados no cenário baiano.

\section{O CENÁRIO LEGAL DAS PROIBIÇÕES RELIGIOSAS AFRICANAS E A MOLDURA RACISTA}

Apesar da conquista de alguma liberdade por determinados escravos e ex-escravos na Bahia, o cenário da escravatura acompanhava-se de um pensamento racista, o qual concebia as tradições africanas como menores e contaminadoras dos "bons costumes" coloniais e brasileiros. A independência brasileira reconhecida em 1825 pelos governos português e inglês, pressupunha o fim do comércio de escravos. Todavia, somente com a famosa Lei Eusébio de Queirós, de 1850, depois de um quarto de século de intenso tráfico negreiro, foi possível abolir definitivamente o comércio de escravos para o Brasil, e somente em 1871, com a promulgação da Lei do Ventre Livre, os filhos de escravos passaram a nascer livres. Ainda assim, foi preciso esperar pelo ano dia 13 de maio de 1888, para que a Abolição da escravatura chegasse ao Brasil, com a Lei Áurea, num dos últimos atos da monarquia brasileira, um ano antes da implantação da república. Pelo meio, o negro foi sendo jogado ao desempenho de inúmeros papéis e estereótipos, a maioria dos quais ainda hoje extremamente operatórios. Conforme Célia Azevedo (1987), a construção de um projeto de nação brasileira embatia no perigo da presença negra ${ }^{5}$. A "poluição" étnica e cultural africana era um significativo entrave para o imaginário das elites brancas, que se inaugura com as rebeliões de escravos a partir da primeira metade do séc. XIX e se perpetua até aos dias coevos. Como Maria Luiza Tucci Carneiro (2003) salienta, a mobilidade social do negro estava dependente da sua capacidade de se branquear, i.e., de adquirir os padrões estéticos das elites brancas, sendo estratégia o alisamento capilar. Conhecemos esse processo, por exemplo, na figura da sacerdotisa Sabina,

5 A Inquisição através das suas Ordenações Filipinas dispunha as religiões africanas como blasfemas e as suas práticas como merecedoras de forte punição (Oro, 2008, p.307). Renato da Silveira (2005) levanta o caso de cinco sacerdotes africanos investigados pelo Santo Ofício no Brasil. 
objeto de duras críticas na época de Ruth Landes (2002: 213). A partir das teorias evolucionistas elaboradas na esteira de Charles Darwin, particularmente alavancado na obra evolucionista do antropólogo francês Charles Letourneau, L'évolution religieuse dans les diverses races humaines, de 1898, o médico legista Raimundo Nina Rodrigues desenvolve as primeiras pesquisas no seio da comunidade afro-baiana, no terreiro do Gantois, ao tempo da sua fundadora. A agenda de Nina Rodrigues resumia-se na procura das heranças africanas mais autênticas com o propósito de hierarquizar os africanos, em superiores e inferiores, conseguindo construir um conjunto de castas na sociedade brasileira, avisando para o perigo da contaminação ascendente, em que a poluição religiosa e cultural africana poderia chegar ao topo, às classes brancas e católicas (1900). Na concepção de Nina Rodrigues, o africano seria superior ao índio, mas inferior ao branco (também ele dividido em inferiores e superiores, do mestiço ao ariano). Colocando os negros yorùbá como a elite africana, dispôs o negro, contudo, pela via da cientificidade da época, ao papel de renegado social, de verdadeiro perigo, poluição e doença social. A religião, naturalmente, serviu de medidor de grau de civilidade do africano, e o médico legista foi claro em considerar que os islâmicos seriam os mais "evoluídos" de entre os negros, ainda que bárbaros. Num trabalho anterior, datado de 1894, Nina Rodrigues propôs que o índio, o negro e o mestiço fossem objeto de estatuto jurídico diferenciado, sendo considerados de responsabilidade civil limitada. Como Capone (2004) adianta, esta ideia permanece veiculada na lei brasileira atual, onde os índios são considerados menores que podem ser legalmente emancipados.

Com efeito, todo este cenário de inferioridade étnica, cultural e religiosa das populações negras, emoldurava um cenário de proibição e intensa perseguição religiosa. A Constituição de 1823 estabelecia que a liberdade religiosa no Brasil compreendia, exclusivamente, o cristianismo, sendo que, de acordo com o artigo $16^{\circ}$ da mesma, as demais formas de religiosidade seriam, apenas, toleradas. Com o advento da República, em 1889, a liberdade religiosa tornava-se um imperativo. Porém, “foi preciso, então, encontrar outros elementos de descriminação entre cultos religiosos legítimos e ilegítimos: o exercício de medicina e a prática de feitiçaria passaram a ser pretextos para a repressão aos cultos afro-brasileiros" (Capone, 2004, p.224). Assim, com este espírito de formulação ideológica, o Artigo $157^{\circ}$ do Código Penal de 1890 condenava a prática do espiritismo, da feitiçaria, magia, curandeirismo, este último considerado prática ilegal de medicina, bem como a adivinhação, com destaque para a cartomancia, extremamente difundida entre as classes mais altas brasileiras. Na verdade, sabemos que uma fatia importante da clientela dos calundus e mais tarde dos terreiros de Candomblé, advinha dessas mesmas classes, razão pela qual o medo de 
contaminação e impureza era tão vincado. Essa circulação produzia uma noção de eficácia negativa das religiões afro-brasileiras: por serem eficácias, por produzirem efeitos, ao mesmo tempo que são crendice e falsa religião, elas devem ser combatidas. Este misto de medo e descrença, produziu efeitos legais profundos (Mandarino, 2007).

Há, portanto, um intenso processo de marginalização social e legal, que visa, num quadro de modernidade, livrar-se da marca africana. A memória histórica dos terreiros de Candomblé, veiculada pelas gerações anteriores, relata a necessidade de inscrição dos terreiros em Secretarias de Segurança Pública, e a autorização de culto pela polícia da jurisdição. Há relatos orais e documentais que dão conta da repressão policial vivida. Na memória da Casa de Oxumarê, histórico terreiro baiano, guardam-se episódios de celebrações interrompidas por polícia montada. Inúmeros terreiros foram alvo de apreensão de objetos rituais, da detenção de participantes, e destruição de altares. Até há trinta anos atrás, era proibida a presença de menores em festividades religiosas. No terreiro da Casa Branca, conta Edvaldo Araújo, oficiante religioso responsável pela música sacra, o alabê, havia uma tabuleta que indicava que o Candomblé era proibido para menores de idade. Ele e outros membros de terreiros baianos relatam a forma como se escondiam das batidas policiais, mantendo-se debaixo das saias das mulheres ou atrás dos altares. Era frequente a retirada das crianças das suas comunidades e a entrega destas a instituições e orfanatos. O clima de terror adentrava a porta dos terreiros. Angela Lühning, num trabalho clássico (1996), dedica a sua atenção à figura de Pedrito Gordilho, eternizado no romance de Jorge Amado, Tenda dos Milagres, sob o nome de Pedrito Gordo. Pedro Azevedo Gordilho, delegado policial em Salvador, é registrado na memória oral e na literatura de Amado como o mais violento perseguidor do Candomblé. As batidas policiais na época eram frequentes, e eram incitadas pela imprensa. Parés (2006) dá conta da influência de jornais como O Alabama, mantidos por negros avessos ao Candomblé, na perseguição policial, informando onde teriam lugar as mais diversas celebrações. Para além da perseguição às celebrações do Candomblé, sob o pretexto do "barulho dos atabaques", os ebós - rituais de oferenda, sacrifícios e outros - foram, também, elemento estruturante da perseguição religiosa. É dessa época a expressão "chuta que é macumba", incitando os populares a pontapearem qualquer oferenda ritual encontrada em elementos naturais ou urbanos considerados hierofanias, em particular as encruzilhadas ${ }^{6}$. Como refere Lühning, existem queixas populares em relação aos ebós, considerados um problema de higiene pública.

6 As encruzilhadas simbolizam, no universo candomblecista, regência de Exú, pela sua dimensão múltipla, representando as mais variadas possibilidades e caminhos. Exú é o Orixá dos caminhos, das trocas comerciais, sexuais, da linguagem, razão pela qual cedo foi sincretizado com o diabo cristão. 
Efetivamente, o "barulho" e a "higiene" foram justificações para levar a cabo uma campanha contra o Candomblé. Apesar dos casos de alguma proteção policial, na sua maioria, os terreiros passaram por um clima de instabilidade e insegurança, espelhando o preconceito, o racismo e a intolerância religiosa, justificados pela necessidade de ordem pública. Com efeito, a repressão policial não ficou circunscrita nem à Bahia, nem a Pedrito Gordilho na década de 1930, constituindo-se um fenômeno fundacional e de longo-termo. Foi a repressão policial e governamental que levou a comunidade da Barroquinha a mudar-se para o Engenho Velho (Silveira, 2006), nos primeiros anos do Candomblé. O clima de terror vivido em Salvador tem respaldo noutros lugares do Brasil. Em Sergipe, a perseguição às religiões afro-brasileiras sofre grande incremento nas décadas de 1930 e 1940. De acordo com Mandarino (2007), naquela região, com base na lei do silêncio, eram perseguidos todos os que estivessem fora de casa a partir das 22 horas, estando enquadrados na lei, por intenção clara, as prostitutas, os bêbados, e os "macumbeiros", o coletivo dos "marginais" e desestabilizadores da ordem pública. Uma vez que as celebrações do Candomblé ocorrem, historicamente, desde a escravatura, de noite, correspondendo ao período póslaboral, a lei do silêncio permitia combater a existência destas religiões, contornando a liberdade religiosa oficial. No Rio de Janeiro, durante o mesmo período, correspondendo, portanto, ao Estado Novo, a repressão policial também se fez sentir, continuando, aliás, um périplo desde a Inquisição (Oliveira, 2015), altura em que se criou a Secção de Tóxicos, Entorpecentes e Mystificações, em que as religiões afro-brasileiras, a pretexto da prática ilegal de medicina (curandeirismo) se viram acompanhadas de inúmeras denúncias, criminalizações e perseguição. A própria Igreja Católica desempenhou importante papel no combate às religiões afro-brasileiras, na década de 1950, ao fazer apologia do combate às religiões não-cristãs e ao ativar a sua extensa rede de influências no espaço político e mediático (Oro \& Steil, 1997; Correa, 1998). Mais, na década de 1970, a Igreja Católica reforça a sua posição oficial contra as religiões afro-brasileiras, com um pedido de censura por parte da Arquidiocese do Rio de Janeiro (Oro,2008, p. 3011-12).

\section{UMA TENTATIVA DE APAZIGUAMENTO PELOS INTELECTUAIS}

Como visto, um background de pendor científico permitiu construir um cenário de perseguição a tradições africanas. O papel de Nina Rodrigues havia sido determinante no período pós-abolição. No entanto, à medida que ia participando mais ativamente no terreiro do Gantois, Nina Rodrigues ia alterando o seu posicionamento. ${ }^{7}$ Entre a publicação de O Animismo Fetichista

7 Seeber-Tegethoff (2007) e Lisa Earl Castillo (2010) relatam a forma como os pesquisadores e os terreiros se vão 
dos Negros da Bahia (1900) e de Os Africanos no Brasil (1906), o médico legista assume o papel de defesa dos cultos de manifesta identidade nagô (yorùbá) diante das demais 'nações de Candomblé' e outras formas de culto. ${ }^{8}$ A repressão policial é objeto de crítica do médico legista neste seu segundo livro. Quase três décadas depois, em 1934, Artur Ramos, discípulo de Nina Rodrigues, no seu livro O negro brasileiro, opõe religião e magia, expressando esse antagonismo nas figuras do sacerdote do Candomblé e no curandeiro. Desta forma, Ramos pretende contribuir para a redução da repressão policial face aos cultos afro-brasileiros, distanciando religião africana de falsa medicina. Três anos após $O$ negro brasileiro, o país entra no Estado Novo, proclamado por Getúlio Vargas, inaugurando uma nova política de repressão às minorias. Nos estados de São Paulo e Rio Grande do Sul, marcados por fortes vagas migratórias, deram-se intensas inspeções que visavam impedir a utilização de línguas estrangeiras nas escolas (Capone, 2004, p.231). Uma vez que este é um período em que o Partido Comunista Brasileiro é fundado, a repressão aos terreiros agudiza-se, considerando que estes são espaços de disseminação de ideias comunistas e contrárias ao regime.

A criação do Serviço de Higiene Mental do Rio de Janeiro e o homólogo do Recife, na década e 1930, marcaram uma nova fase no tratamento das religiões de matrizes africanas no Brasil. Retirando determinados terreiros da pressão policial, garantindo uma maior liberdade de culto, estas instituições preservavam, ainda assim, fortemente, a noção de inferioridade, de desvio, de problema de ordem sociológica e, acima de tudo, psiquiátrica. A possessão ou transe ritual, parte significativa destas religiões, representava um estudo de caso relevante, fenómeno considerado como delírio religioso (Capone 2004: 231). A fim de garantir a livre prática do culto, os terreiros de Xangô do Pernambuco livremente se colocaram sob a tutela destas instituições psiquiátricas, disponibilizandose para a abordagem preconceituosa e para a catalogação como patologia religiosa, diante da verdadeira religião: o catolicismo histórico.

Alguns intelectuais brasileiros, nas décadas de 1930, 1940 e 1950, em particular emergentes do seio cultural afro-brasileiro, como Edison Carneiro (1936) ${ }^{9}$, empenharam-se em alinhavar o Candomblé nagô com o idioma da "pureza africana", contrapondo, para tanto, os modelos de tradição angolano-congolesa, genericamente chamados bantos e, principalmente, as macumbas

articulando e influenciando mutuamente.

8 As nações de Candomblé (Costa Lima, 1976) correspondem a estruturações ideais que visam recriar as identidades étnicas autóctones africanas aportadas ao Brasil, agora com um sentido político-religioso.

9 A Cidade das Mulheres, obra emblemática de Ruth Landes (1947) foi condicionada pela gestão do trabalho de campo de Edison Carneiro. A antropóloga norte-americana assimilou a narrativa nagôcêntrica, ao mesmo tempo que ofereceu a Carneiro a sua agenda feminista, contribuindo para a estigmatização da figura do homossexual na sociedade brasileira e no seio dos terreiros afro-brasileiros (Matory, 2008). 
cariocas. Esta lógica é ampliada e cristalizada, definitivamente, com o trabalho de Roger Bastide, que publicaria, em 1958, a sua obra mais emblemática, Candomblés da Bahia. Procurando valorizar o segmento nagô, Carneiro revitaliza a figura de Exú, o deus da comunicação, demonizado por missionários e pesquisadores ocidentais, mas somente no seio dos terreiros nagôs, onde o ritual do padê, conhecido por "despacho de Exú", passa a ser interpretado não como um ritual que visava "mandar embora" esse deus malévolo, esse demônio, mas antes torna-lo embaixador junto dos demais deuses (1948, p.69). Dessa forma, Bastide impõe uma fronteira entre os nagôs e os bantos, cabendo aos primeiros o culto de Exú-mensageiro, e aos segundos a de Exú-diabólico. Esta ideia é transposta para o As religiões africanas no Brasil, obra de 1960, e para o ensaio "Imigração e metamorfose de um deus" (1956), em que opondo os nagôs aos bantos expressa o binómio religião/ magia, inscrevendo o Candomblé no discurso racial-científico da época.

\section{O CONTEXTO ATUAL DA REPRESSÃO AOS CULTOS AFRODESCENDENTES}

Efetivamente, o cenário de perseguição marca a existência longue durée das religiões afrobrasileiras no campo religioso brasileiro. Schritzmeyer (2004), mostrou a relação, no imaginário social e judiciário, entre a ideia de charlatanice e curandeirismo e as religiões africanas no Brasil, deixando claro que aquelas jamais foram concebidas como religiões de fato. Quer isto dizer que as mesmas sempre se encontraram envoltas em teorias científicas e avaliações judiciárias como "polutas", "inferiores", “desestabilizadoras da ordem" e "responsáveis pelo atraso civilizacional brasileiro", mantendo as classes inferiores num estado "primitivo" e contaminando as classes superiores com as suas crendices e falsos deuses. Esperava-se que o advento do governo de Luís Inácio Lula da Silva, marcado, por exemplo, pela criação do "Dia de Combate à Intolerância Religiosa", sancionada pela Lei ${ }^{\circ} 11.635$, de 27 de dezembro de 2007, marcasse uma nova etapa na vivência religiosa brasileira, reforçando o disposto na Lei $n^{0} 7.716$, de 5 de janeiro de 1989, alterada pela Lei $n^{\circ}$ 9.459, de 15 de maio de 1997, que estipula como crime a prática da discriminação e do preconceito religiosos. Todavia, a aderência da lei à realidade social é, muitas vezes, um processo moroso. Não obstante o disposto legalmente, a perseguição aos templos afro-brasileiros é uma realidade em crescendo, extrapolando o domínio do judiciário e adentrando por um fenômeno de "guerra santa", levada a cabo pelas igrejas evangélicas neopentecostais.

Conforme nos recorda Ari Pedro Oro (2008), os ataques das igrejas neopentecostais às religiões afro-brasileiras é um fenômeno ab initio. Na década de 1960, o pastor evangélico 
canadiano Robert McAlister instala-se no Rio de Janeiro, onde funda a Igreja Nova Vida. No processo de acomodação religiosa, o pastor reconhece o espaço das religiões afro-brasileiras no mercado carioca, empregando, assim, uma ressignificação e ressemantização das entidades dos universos afro-brasileiros, agora com uma roupagem cristã-evangélica de demônios. Em 1968, o pastor publica o seu livro Mãe de Santo. Nele, "afirma estar revelando a verdadeira fonte do poder inerente às práticas afro-religiosas: a inspiração do demônio (...) não há a negação do estatuto mágico dessas religiões e sim sua negativização, que conduz ao seu combate” (Oro, 2008, p.313). A partir dessa "revelação" McAlister lançaria as bases para o combate às religiões afro-brasileiras que se alastraria a outras igrejas neopentecostais posteriores, nomeadamente à IURD, conhecida como a igreja de Edir Macedo, anterior membro da Igreja Nova Vida, e a outros canais de maior divulgação, saindo da doutrinação intramuros da igreja para a comunicação social, recuperando e alargando um processo histórico iniciado na viragem do séc. XIX para o séc. XX. Voltando, ainda, a Oro, o autor inscreve o problema nas fronteiras jurídicas da liberdade religiosa:

A regulação jurídica desses ataques, embora tenha conseguido desmobilizar o radicalismo dos discursos intolerantes dos neopentecostais, é de difícil implementação, posto que é quase impossível interpretar esses ataques como crime contra o sentimento religioso alheio sem, com isso, cercear a própria liberdade religiosa neopentecostal (p. 314).

Com efeito, aquilo que Oro nos quer transmitir é que tais igrejas possuem uma identidade contrastativa, pelo que necessitam das religiões afro-brasileiras para se identificarem. É pelo combate ao demônio personificado no "outro", o afro-religioso, que se permitem expressar quer do ponto de vista teológico quer como ação ritual. Nesse sentido, é um desafio jurídico tremendo para as instituições brasileiras delimitarem as fronteiras da ação religiosa, do proselitismo e da salvaguarda da liberdade e dignidade religiosas. Como garantir o direito ao livre e digno exercício da prática e consciência religiosa afro-brasileira sem, com isso, limitar a ação das igrejas neopentecostais? Como controlar a ação religiosa que se baseia na guerra contra o "outro"? Conforme Vágner Gonçalves da Silva recorda (2007, p. 310), o cenário em questão evidencia uma "guerra espiritual", cujos contornos doutrinários foram definidos na literatura neopentecostal, com grande destaque para o já citado livro de Robert McAlister e para o livro de Edir Macedo, fundador da IURD e seu líder atual, publicado em 1988, Orixás, caboclos \& guias. Deuses ou demônios? A colocação do título como pergunta permite ao autor dar a evidente afirmativa resposta, trazendo "evidências" da ação demoníaca através das religiões afro-brasileiras. 
O citado trabalho de Gonçalves da Silva representa um importante levantamento etnográfico dos mais variados casos de intolerância e perseguição religiosa contra as religiões afro-brasileiras, levadas a cabo, direta, ou indiretamente, por tais igrejas. Das palavras de incitamento ao ódio em cultos e na imprensa, matérias noticiosas carentes de imparcialidade e de forte pendor anti-afrobrasileiro, atos claros de violência física contra terreiros e membros de terreiros, ataques a cerimônias públicas ou lugares públicos de valor religioso afro-brasileiro, ataques resultantes das alianças estabelecidas entre igrejas evangélicas e políticos evangélicos, ou entre igrejas evangélicas e chefes de tráfico nas ditas "favelas", ou ainda entre igrejas evangélicas e membros da polícia. O cenário evidencia a dimensão combativa e a capacidade de produzir engajamento militarizado à cruzada evangélica. Um dos casos mais emblemáticos é o de Kayllane Campos, que em 2015, com 11 anos de idade, foi apedrejada na cabeça, quando saía do terreiro de Candomblé, no Rio de Janeiro, após cerimônia religiosa. A sua avó, mãe de santo (sacerdotisa) relata as contínuas ofensas verbais prévias ao ataque, o qual marcou a passagem da ofensa verbal à física. ${ }^{10} \mathrm{O}$ fato de Kayllane ser filha de uma mulher evangélica, não lhe garantiu segurança, deixando escapar os caminhos pelo qual o preconceito se move. No contexto brasileiro, o caso Kayllane é apenas um ponto de luz num imenso holofote. Como resposta, dele resultou uma manifestação que juntou 400 pessoas no Rio de Janeiro. De acordo com dados compilados pela Comissão de Combate à Intolerância Religiosa do Rio de Janeiro (CCIR), mais de 70\% das 1.014 denúncias de ofensas, abusos e atos violentos registrados no Estado entre 2012 e 2015 são contra praticantes de religiões de matrizes africanas. Estes dados são sintomáticos de um estado de perseguição religiosa sem par no Ocidente, distribuída em ofensas verbais diretas, violência física contra indivíduos de religiões afrobrasileiras, contra templos, contra elementos e lugares representativos destas religiões, como a estátua de Iemanjá na Tijuca, no Rio de Janeiro, que desde a sua inauguração, em 1973, já foi destruída quatro vezes ${ }^{11}$, ou o mural da Casa de Oxumarê, histórico terreiro de Salvador, que no passado mês de agosto de 2017 , foi vandalizado, tendo sido pintado sobre uma representação de Oxumarê, deus do arco-íris, das transformações, da chuva e do movimento, uma representação evangélica, com um livro e a inscrição "O senhor é o meu pastor nada me faltará! Salmo 23:1" 12 . Inúmeros exemplos servem para ilustrar o cenário de intensa perseguição. Também em agosto de

$10<$ http://g1.globo.com/globo-news/noticia/2015/06/minha-fe-vai-sempre-continuar-diz-menina-que-levou-pedradaapos-culto.html>, acessado em 1 de setembro de 2017 .

11 <https://oglobo.globo.com/eu-reporter/vandalos-destroem-estatua-de-iemanja-na-praia-da-barra-4405546>, acessado em 3 de setembro de 2017.

$12<$ https://z-m-scontent-mad.xx.fbcdn.net/v/t1.0-9/20294390_1528115450545021_5925070370391849624_n.jpg? _nc_ad=Z-m\&_nc_cid=1272\&oh=6f2ce2554f6c439669fc303ea4008715\&oe $=5$ A5290EE $>, \quad$ acessado em 3 de setembro de 2017 . 
2017, em Vitória, no Espírito Santo, um pastor da Igreja Evangélica Batista de Vitória, fez um pedido de remoção de uma boneca Abayomi, desenvolvida como parte de um projeto de promoção da diversidade étnica e religiosa na região. De acordo com o pastor, em reportagem publicada no portal de notícias da Globo, o G1, "Aquilo era um quadro com entidade de macumba. Se colocar qualquer símbolo religioso que confronte a Bíblia eu tiro, eu tirarei e, se repetir, eu tiro de novo". Recorde-se que o espaço, o Centro Municipal de Ensino Infantil (Cmei), funciona num edifício pertencente à igreja, mas alugado à Prefeitura. A negociação dos espaços reflete os conflitos emergentes no campo religioso brasileiro. A convivência é um exercício de gestão de conflitos e contrastes, particularmente num cenário onde noções como verdade e proselitismo operam determinantemente. Em consequência da frequência dos ataques, terreiros de Candomblé e Umbanda decidiram investir na segurança, instalando câmeras ou reforçando o acesso ao local, com arame farpado e gradeamentos. Ainda assim, a determinação de membros da comunidade evangélica na sua cruzada contra as religiões afro-brasileiras continua a causar danos. Pai Costa, zelador umbandista na zona norte do Rio de Janeiro, conta - em depoimento à BBC Brasil - que, apesar do sistema de alarme e vídeo-vigilância, "Há duas semanas, na quarta invasão, arrombaram os cadeados e passaram pelo portão, quando o alarme foi disparado. Só deu tempo de pegarem uma imagem próxima e quebrá-la na calçada. Não conseguiram chegar até o salão [local de cerimónias públicas]"13. No dia 20 de agosto de 2017, uma mulher de 65 anos foi apedrejada por uma vizinha evangélica, em Nova Iguaçu, no Rio de Janeiro, depois de um historial de violência verbal ${ }^{14}$. Menos de um mês antes, na Penha, também no Rio de Janeiro, o Ilê Axé Obá Inã, terreiro de Candomblé, foi alvo de apedrejamento, danificando seriamente o telhado do templo ${ }^{15}$.

O fenômeno da violência religiosa não é, todavia, circunscrito aos dois últimos anos. É possível recuar no tempo e encontrar outras notícias que dão conta de investidas da mesma natureza, consubstanciando um processo em que a violência adquire uma dimensão teológica, justificada e ungida pelo combate aos terreiros como encarnação do mal, como lugares de presença e culto demoníaco. Efetivamente, a constituição de uma teologia bélica produz os seus efeitos na criação de forças armadas, entre eles traficantes convertidos, que no seu papel de detentores do poder nas comunidades designadas por "favelas", exercem coação sobre os terreiros, expulsando-os

$13<\mathrm{http} / /$ www.bbc.com/portuguese/noticias/2015/06/150625_intolerancia_religiosa_terreiros_pai_jp $>$ acedido em 4 de setembro de 2017.

$14<\mathrm{http} / /$ g1.globo.com/rio-de-janeiro/noticia/idosa-e-agredida-a-pedradas-e-familia-denuncia-intolerancia-religiosaem-nova-iguacu.ghtml $>$ acedido em 4 de setembro de 2017.

$15<$ https://extra.globo.com/casos-de-policia/um-rio-de-odio-terreiro-de-candomble-atacado-com-pedras-ovoslegumes-podres-21645654.html>, acedido a 5 de setembro de 2017. 
do local. ${ }^{16}$ Enquanto "guerreiros de Jesus", estes traficantes encontram redenção nos seus atos, purificando-se dos pecados através da guerra, enquanto atualizações dos cruzados. Exemplo desta dinâmica é o do terreiro da Mãe Conceição, localizado em Duque de Caxias, no Rio de Janeiro, que em 2014 já havia sido atacado oito vezes ${ }^{17}$. Ataques continuados ao mesmo espaço religioso tem um efeito de desgaste psicológico e de violência simbólica, entregando a comunidade ao receio permanente. É o caso do Ilê Axé Omó Omin Tundê, terreiro de Candomblé situado na Ilha Amarela, na região metropolitana de Salvador da Bahia, que até março de 2016 foi atacado três vezes ${ }^{18}$, ou o terreiro Ilê Aira Axé Mesan Orun, localizado em Valparaíso de Goiás ${ }^{19}$. Outro caso ocorreu no início de 2017, em que o terreiro de Candomblé e Umbanda, Ilê Axé Ogum Xoroquê, situado no bairro Boa Vista, Rio de Janeiro, foi atacado por três vezes apenas em $2017^{20}$. De acordo com a Secretaria Estadual de Direitos Humanos, somente entre julho e agosto de 2017, no Rio de Janeiro, foram registradas 32 denúncias de ataques de intolerância religiosa contra terreiros. Instigar o medo é o principal objetivo, procurando que as comunidades-terreiro abandonem o local. Um sentimento de vigilância permanente e receio mina muitos terreiros de Candomblé e Umbanda. Em março de 2016, durante cerimónias iniciáticas no terreiro Pilão de Prata, em Salvador, na Boca do Rio, um grupo de membros de uma comunidade evangélica, munidos de megafones, esteve à porta do templo a rezar e a exorcizar o mesmo, obrigando à paragem dos rituais, por um período de horas, até ao abandono do local. Durante trabalho de campo realizado em 2015, na cidade de Uberaba, no Estado de Minas Gerais, foi possível perceber a presença de segurança privada na entrada de terreiros, justificada com a ameaça de ataque iminente por parte de membros das comunidades evangélicas locais, cada vez mais radicalizadas. O processo de combate ultrapassa os ataques aos terreiros, visando automóveis com elementos afro-religiosos, como colares de missangas, correntemente chamados de "guias", e pessoas em espaços públicos portando elementos identificadores, sejam tatuagens alusivas aos Orixás ou a elementos identificados como parte do acervo simbólico afro-religioso, ou portando os colares ao pescoço, constando-se casos como de

$16<$ https:/extra.globo.com/noticias/rio/traficantes-proibem-candomble-ate-roupa-branca-em-favelas-9892926.html > acedido a 5 de setembro de 2017; <http://midiabahia.com.br/cotidiano/2016/11/02/traficantes-evangelicosexpulsam-maes-de-santo-de-favelas-no-rio/> acedido a 5 de setembro de 2017.

$17<$ http://odia.ig.com.br/noticia/rio-de-janeiro/2014-07-31/mae-de-santo-que-teve-terreiro-atacado-oito-vezes-pode-servitima-do-trafico.html $>$, acedido a 3 de setembro de 2017.

$18<$ http://informebaiano.com.br/37/noticia/terreiro-de-candomble-e-atacado-pela-terceira-vez-em-salvador $>$, acedido a 3 de setembro de 2017.

$19<\mathrm{http}$ //www.correiobraziliense.com.br/app/noticia/cidades/2015/12/03/interna_cidadesdf,509120/terreiro-noentorno-do-df-e-atacado-pela-terceira-vez-em-menos-de-um-a.shtml>, acedido a 3 de setembro de 2017.

$20<$ http://m.cbn.globoradio.globo.com/editorias/policia/2017/09/14/MAIS-UM-TERREIRO-DE-CANDOMBLE-EALVO-DE-CRIMINOSOS-NO-RIO.htm> acedido a 15 de setembro de 2017. 
expulsões de transportes públicos.

A conquista de geografias religiosas é parte do ativo destas igrejas. É sabido que a expansão das igrejas evangélicas ocorre em territórios de presença de terreiros, geralmente edificadas lado-alado. Não raras vezes, os cultos evangélicos ocorrem em horário coincidente com as celebrações nos terreiros, num duelo que marca o campo religioso brasileiro. Efetivamente, a noção de combate religioso, de guerra santa, evidencia a dinâmica maior do campo religioso e da atuação das igrejas neopentecostais. Para além das religiões afro-brasileiras, são alvo elementos católicos, desde igrejas à sua iconografia. Em 2015, em Piedade, no Estado de Minas Gerais, uma mulher foi presa depois de ter sido filmada a destruir com uma enxada a estátua de Nossa Senhora da Piedade ${ }^{21}$. Mais recentemente, na cidade de Carrapateira no estado da Paraíba, um grupo de membros da comunidade evangélica local "quebram, urinam e ateiam fogo em imagem de Nossa Senhora" ${ }^{22}$. O mais conhecido episódio, todavia, é o "chute na santa", ocorrido em 1995, em que o bispo Sérgio Von Helde, na época membro da Igreja Universal do Reino de Deus (IURD), em direto na televisão pontapeou uma imagem de Nossa Senhora da Aparecida, tida no imaginário popular como a padroeira do Brasil. Uma vez que o acontecimento atentou contra elemento iconográfico católico, num país onde mais de setenta por cento da população se assume como tal, os efeitos foram avassaladores, tendo o bispo em questão sido condenado a pena de prisão, após um enorme levante popular, político e mediático. A força normativa do catolicismo, faz com que esta religião seja menos visada na guerra santa levada a cabo pelas igrejas neopentecostais.

\section{OS SACRIFÍCIOS ANIMAIS COMO DESESTABILIZADOR SOCIORRELIGIOSO}

A história dos eventos de alteridade comporta uma dimensão de preconceito. A experiência do «outro» veicula os paradoxos e os antagonismos culturais, sendo, tal cenário, particularmente evidente nos encontros afro-europeus. As visões deturpadas e demonizadas das religiões africanas ajudaram a perpetuar um cenário de racismo biológico e combate religioso. Conforme nos contextualiza Anderson Oliva (2005, p. 14), a visão cristã acerca de África é polida na "passagem bíblica sobre os descendentes de Cam e a da transposição da cosmologia celestial católica para a cartografia terrestre, localizando na África o inferno na Terra”. Este cenário construído desde a Idade Média, a partir do conhecimento da existência do continente africano e, mais tarde, dos

$21<$ http://g1.globo.com/mg/vales-mg/noticia/2015/03/mulher-e-presa-destruindo-imagem-de-igreja-com-golpes-deenxada-em-mg.html $>$, acedido em 7 de setembro de 2017.

$22<\mathrm{http}: / /$ www.dicasonline.tv/evangelicos-quebram-imagem/>, acedido a 7 de setembro de 2017. 
primórdios da presença europeia no continente africano, permitiu extrapolar a realidade através do imaginário cristão, povoado de figuras demoníacas e do combate eterno entre o Bem e o Mal. A antropofagia fazia parte do imaginário europeu acerca de África, desde o século XVIII até ao século $\mathrm{XX}$, uniformizando o continente africano. Em referência ao espaço geográfico que remete aos cultos dos Orixás, os relatos de missionários e viajantes contribuíram para a construção de uma imagem nefasta dos povos yorùbá. Desses trabalhos destacam-se os de Bosman, Voyage de Guinée, de 1705, Francesco Borghero, Le Dahomé, souvenirs de voyage et de mission, de 1872, Noeil Baudin, Fétichisme et féticheurs, de 1884 e o de Pierre Bouche, La Côte Des Esclaves et Le Dahomey, de 1885. Tratam-se de relatos marcados pelo imaginário judaico-cristão, em que se demonizam os deuses africanos e os negros, considerando as suas crenças ridículas, e os deuses como aberrações, assemelhados aos mais feios negros viventes:

Os feiticeiros são seres desprezíveis, mentirosos, preguiçosos, hipócritas, impudicos e refinados ladrões. Geralmente têm um aspeto sujo, vestimentas ridículas e esfarrapadas, e os que molham as mãos em sangue humano têm um ar bestial, feroz e repugnante (Baudin, 1884, p.86).

Um caldo teológico e racial nefasto estava determinantemente em marcha, marcando o contexto europeu, africano e do Novo Mundo. Para tanto, basta ver a forma como Exú, o Orixá mensageiro, o senhor da comunicação e das trocas, foi utilizado como equivalente ao Diabo (Dopamu, 1990; Prandi, 2001; Capone, 2004; Oliva, 2005; Ferreira Dias, 2011; et. al.). De entre os elementos mais marcantes da religiosidade africana, que muito atentou ao imaginário cristão, e que permanece como entrave à difusão do Candomblé, encontram-se os ritos sacrificiais. Tal fato conduz-nos a uma teia de significados não apenas do sangue como da troca simbólica e do valor implícito da comida, cujos contornos não se apartam da noção cristã de "corpo de Cristo", mas que por possuírem uma roupagem africana, pelo viés histórico mencionado, adquirem uma dimensão demonizada. Marcel Mauss (1988) desenvolveu a teoria sobre os ritos e as trocas que permanece operatória no seio das ciências sociais. O sacrifício enfatiza a troca, a reciprocidade estabelecida e contínua, o contrato de expectativa, em que os Homens se comprometem a manter o sacrifício e os deuses se comprometem a não faltar aos pedidos. ${ }^{23}$ Há uma retribuição e uma dádiva compondo o ciclo da existência religiosa. O animal utilizado em ritual, sacrificado, i.e., tornado sagrado, do

23 R. Hallgren (1988) ao trabalhar a religião dos yorùbá utiliza o conceito de "as coisas boas da vida" ("The Good Things in Life") para explicar as dimensões sociológicas da religião, reforçando a oposição a uma visão postmortem própria do cristianismo, onde a salvação é o fim último. 
latim sacrificium, torna-se alimento, um alimento partilhado entre o humano e o divino. E. B. Tylor (1871), num trabalho clássico da antropologia britânica do séc. XIX, enfatiza a importância dos sacrifícios na constituição de uma relação entre os humanos, que ele ali alude como "os selvagens", e os deuses, considerando-se que tal veículo permite uma ligação conveniente, pois a ausência de ofertório afasta os deuses do quotidiano humano, causando prejuízos na ordem das coisas. No entanto, se a disposição para o sacrifício é justificada na proposta teórica de Tylor, Marcel Mauss e Henri Hubert (1981) consideram necessário ampliar o quadro teórico, tornando-o capaz de albergar a mecânica ritual. Os mesmos encontram uma partilha mecânica mais ou menos universal, observando no rito sacrificial uma mecânica ativadora social e religiosa, um processo pelo qual se dá a comunhão religiosa, um ato que transforma a vítima em, digamos assim, objeto comunicante. $\mathrm{O}$ animal sacrificado é o elemento ordenador da sociedade, o que repõe a ordem e o equilíbrio social e natural, propiciando a presença dos seres espirituais e a sua boa-vontade. A consagração do animal, durante o ritual, acarreta a transformação simbólica de vítima a objeto comunicante. Por essa razão é metodologicamente necessário afastar o conceito de "vítima", pois que não se dá, naquele quadro cosmológico, um assassinato. Uma vez que ocorre num espaço sacralizado, em que os objetos são exclusivos para os rituais, desde a faca aos altares onde o sangue (e em alguns casos, como no Candomblé, outras partes do animal) será depositado, estamos diante de uma dimensão sagrada, em que o ritual comunica e comunga os presentes. Regressando a Mauss e Hebert, encontramos no ritual um ato de abnegação da parte do objeto comunicante, seja ele animal ou humano. Efetivamente, quando olhamos para horizontes mais próximos, encontramos a recorrência do sacrifício humano como parte da relação entre o ser humano e o plano espiritual-religioso. Entre os Viking era comum a oferenda sacrificial humana (Langer, 2003), constituindo-se uma honra ser escolhido para esse propósito. A prática era também corrente na Grécia Antiga (Hughes, 1991) e na Mesoamérica (Wilkerson, 1984).

Recontextualizando: o sacrifício constitui-se um contrato entre o humano e a divindade, que consubstancia a dádiva e a troca. Trata-se de um ciclo permanente, que se renova a cada oferenda, em que os seres espirituais, os deuses, são ressarcidos, possibilitando novas dádivas à humanidade. Há, portanto, como Mauss e Hubert defendiam, um duplo viés: utilidade e obrigação. Ao apresentar uma dimensão útil, o sacrifício adquire uma dimensão econômica, pois que coloca em relação de troca humano e sagrado, ativando, simultaneamente, a obrigação, pois que, etimologicamente, obrigação, é um ato em que o sujeito se obriga a algo perante o outro. Assim, a obrigação é o dever de restituição, de retribuição, de cumprimento da troca, num ciclo permanente de relação. Há, ainda, 
uma outra dimensão de troca, que é a vida do animal sacrificado pela nossa: lati gba orí ẹran gbà daju orí $m i$ - "aceite a cabeça do animal comprometendo-se a deixar a minha". Assim é dito em yorùbá. Essa troca formalizada, contratualizada, implica, evidentemente, uma transformação do objeto comunicante em sagrado - consagração. É por isso que os animais utilizados nos rituais do Candomblé são lavados e limpos, muitas vezes cobertos por panos decorativos ou totalmente tapados para a caminhada que fazem até ao lugar de sacrifício, uma via sacra, ocasião em que se tornam sagrados, estando assim velados. O ato de velar os animais, de os cobrir dos olhos profanos, encontra coincidência no provérbio yorùbá: "Biri-biri bò wọn lójú, Ògbẹri nko mo màrìwò" “escuridão cobre os seus olhos, o não-iniciado não pode conhecer os segredos do mariô" (folha do dendezeiro, metáfora para culto). Há, portanto, um processo de transformação do animal em elemento sagrado, e assim em alimento.

Com a transformação do animal em alimento, para além da consagração e da troca, dá-se um processo de participação, em que a "mesa" invoca a presença dos Orixás, e a comunhão sagrada. Escreve Vilson Caetano de Souza Jr. (2009, p.31):

Nos terreiros de candomblé, o cardápio ritual, ao lado do "feijão com arroz" comidos no dia a dia, na maioria das vezes cozinhados no mesmo fogão, sobre a mesma chama, assim como o comer, obedecem à prescrições expressas nas maneiras de fazer, nas formulações das palavras ditas, conversadas com os ancestrais, nas formas de servir e sentar-se à mesa.

A gastronomia é central na vida religiosa afro-brasileira, seja como oferenda, seja como alimento para partilhar entre a comunidade-terreiro e esta com os visitantes, seja ainda como elemento ritual, nos designados "ebós", trabalhos rituais para diferentes fins, como saúde, emprego, “doenças" espirituais ou situações amorosas. Nesses cenários a comida adquire, igualmente, uma dimensão sagrada e transformativa, ao permitir alterar o decurso dos eventos através da evocação de fórmulas rituais e da consubstanciação espiritual dos alimentos. $\mathrm{O}$ alimento físico transformado em dádiva e objeto comunicante ocupa um lugar decisivo na vida religiosa afro-brasileira (Rabelo, 2013), aparecendo em praticamente todos os rituais, sejam iniciáticos, ofertórios ou de reordenação do caos emocional, espiritual, físico, econômico ou amoroso. Sobre o sacrifício e a oferenda, escreve Mãe Stella:

Os nossos animais são reverenciados desde que são escolhidos nas feiras livres, até o momento em que são oferecidos aos orixás, quando cobrimos seus olhos com folhas específicas de calma e cantamos a fim de diminuir o estresse que eles possam estar 
sentindo. Além disso, eles não são animais quaisquer, são escolhidos aqueles que o sacerdote consagrado para esta função percebe que já estão no momento de passar para outro estágio evolutivo. Não matamos o animal, damos a ele um novo nascimento, por isso cantamos: Bi ewe yeje para lala ie, Ògún pere pa = Demos-lhes um novo nascimento, você resistiu à prova, ultrapassou seguramente privações e sofrimentos, você não está morto, está vivo. Somente Ogun mata. ${ }^{24}$

É, desse modo, possível compreender que o sacrifício no imaginário afro-brasileiro carrega a definição etimológica do termo: tornar sagrado. Assim, ao compreender o cerne da relação entre humano e divino, o sacrifício é envolvo em preceitos regidos, modus ritualia que configuram um ato de enorme devoção, agradecimento e respeito pela vida furtada, dada em troca de ordem, purificação e equilíbrio espiritual, material e comunitário. O sangue, como salienta Elbein dos Santos (1973), é um dos axés (àṣe; i.e., elemento portador de energia vital) mais importantes, seguido da água, da seiva das plantas, do fogo e da terra. O sangue pertence, assim, ao domínio da vitalidade, sendo elemento comunicante, pois a divindade irá "beber" aquele sangue, ao mesmo tempo que institui o altar como sagrado e renova a energia vital. $\mathrm{O}$ sangue é portador de vida por excelência, é o elemento que permite aos objetos se tornarem altares das divindades, moradas dos deuses africanos. E, uma vez que a energia é concebida por perecível, é o sangue que restitui vitalidade aos altares e aos deuses, renovando o contrato e o dom. O sangue de Cristo, representado na missa pelo vinho, representa a formulação católica do poder consagrador e comunicante do sangue, numa lógica não muito distante da que acabámos de enunciar.

Chegamos, então, a um ponto, em que não é possível conceber o sacrifício animal, no quadro afro-brasileiro, como domínio do demoníaco, do nefasto, ou da barbaridade. Cenário, aliás, não imputado ao judaísmo ou islão, religiões que realizam grandes ritos sacrificiais anuais, o que nos leva de volta aos preconceitos acerca de África e suas formas religiosas. Desse modo, compreende-se que a utilização do sacrifício animal como mecanismo de imputação de barbaridade às religiões afro-brasileiras resulta, pois, de uma intenção político-religiosa inscrita neste cenário de guerra santa. Acresce que ao contrário do publicitado nos combatentes das religiões afro-brasileiras, os animais sacrificados não são posteriormente abandonados. Não há uma matança desprovida de um quadro gastronômico utilitário. Ou seja, após sacrificados, todas as partes do animal são recicladas, desde a pele para os atabaques, os tambores sagrados, o sangue para os altares, a carne para alimento da comunidade, e as demais partes serão confeccionadas, segundo os preceitos do

$24<$ http://mundoafro.atarde.uol.com.br/balaio-de-ideias-ritual-e-sacrificio/> acedido a 15 de setembro de 2017. 
terreiro, para serem depositados "no pé do santo", i.e., junto aos altares, para que os deuses "comam" do banquete sagrado ${ }^{25}$ que lhes foi preparado.

Assim, um dos mecanismos mais evidentes de combate às religiões afro-brasileiras, em particular ao Candomblé e manifestações mais africanas do segmento afro-brasileiro, passa pela proibição legal dos sacrifícios animais. Coibir tais práticas representa constranger o modus vivendi destas religiões. Sem o sacrifício, o Candomblé fica impossibilitado de se realizar na sua dimensão ritual, na sua praxis, acantonado para os ofertórios alimentares. Na sua feição prosélita menos evidente, o projeto de combate aos ritos sacrificiais compreende a proteção dos direitos animais ${ }^{26}$. Este cenário é contestado pelos terreiros de Candomblé, que reivindicam o direito ao livre exercício religioso e argumentam que os direitos dos animais não são questionados em relação a matadouros. Existe um evidente cenário de duelo entre os terreiros e as igrejas evangélicas através do instrumento jurídico. Apesar das inúmeras tentativas, a proibição de sacrifícios animais no Candomblé permanece inconstitucional, salvaguardando os direitos das comunidades-terreiros. De acordo com a Instrução Normativa SDA - 3, de 17/01/2000, do Ministério da Agricultura do Brasil, na alínea 11.3,

É facultado o sacrifício de animais de acordo com preceitos religiosos, desde que sejam destinados ao consumo por comunidade religiosa que os requeira ou ao comércio internacional com países que façam casa exigência, sempre atendidos os métodos de contenção dos animais.

Apesar da observação do disposto, o fato da referida lei ser emitida pelo Ministério da Agricultura retira força a um processo de natureza religiosa, haja visto que o garante do direito ao sacrifício deveria constar de uma lei de liberdade religiosa. O Projeto-Lei 1219/2015, no seu artigo $25^{\circ}$, preconiza: “O abate religioso de animais deve respeitar as disposições legais aplicáveis em matéria de proteção dos animais sempre se observando o princípio da dignidade". No entanto, permanece aguardando promulgação.

Desse modo, o abate sacrifical de animais, a consagração ritualizada da carne e do sangue, quando retirada do seu contexto, quando despida do véu sagrado, permite-se ser lido pelo viés da brutalidade, da violação da dignidade animal. Quando inscrito num contexto religioso

25 O "banquete sagrado" é o nome pelo qual é conhecida, também, a cerimónia do Olugbajé (de Barros, 2005; Fonseca, 2007; Camaratta Santos s.d.,), em honra de Obaluaiê (Ọbalúwàiyé) divindade da terra, da palha, das doenças. $26<$ https://noticias.gospelprime.com.br/oab-rj-proibir-sacrificios-animais/> acedido a 24 de setembro de 2017. 
historicamente demonizado, o sacrifício animal configura uma oportunidade de combate religioso, experimentando uma dimensão de justificativa teológica para o combate espiritual.

\section{Conclusão}

A discussão sobre a Liberdade Religiosa no Brasil precisa passar pela reconciliação histórica com as religiões afro-brasileiras, somente possível se estas forem objeto de enquadramento jurídico que as capacitem em matéria de direitos e equidade. Salvo esse caminho, as religiões afrobrasileiras continuarão acantonadas ao seu espaço de minorias, não apenas demográficas, mas acima de tudo num sentido segregatório social e político. Ao longo da história, as tradições culturais (e, necessariamente, religiosas) africanas foram objeto de leituras enviesadas e fortemente devedoras de posicionamentos eurocêntricos, onde a matriz religiosa cristã prevalecia como referencial. O racismo biológico e o evolucionismo trabalharam juntos na produção de deturpações das religiões africanas e suas descendentes nas américas. No cenário brasileiro, a demonização das religiões afro-brasileiras, com particular enfoque ao Candomblé, foi facilitada por uma agenda civilizacional euro-católica, promovendo uma forte legislação que proibia e coibia a livre prática das religiões afro-brasileiras, e facilitava a perseguição desses cultos pelo país. Nesse quadro ideológico, a herança religiosa africana é a marca cultural que necessita ser expurgada do Brasil, por sua inferioridade e capacidade de influenciar negativamente as elites, atentando contra a moral idealizada na esteira cristã, em particular na crescente dimensão político-social evangélica (Machado et. al. 2006; Machado 2006). Com a emergência de um programa ideológico evangélico, a demonização dessas religiões ganha ímpeto militarizado, com uma vaga de ataques populares difíceis de controlar, alimentados por um quadro teológico de "guerra santa". Num contexto em que o «outro» é demonizado como causa da degeneração social brasileira, as práticas sacrificiais representam a materialização do culto demoníaco, tornando-se, a par do "barulho" dos tambores rituais, o pretexto para a ação legal de proibição com fins à extinção de tais religiões, em particular o Candomblé, mais africano. Sabemos que, sem os tambores rituais e, muito particularmente, sem o sangue que consagra os espaços e objetos, o Candomblé não tem viabilidade de subsistir. 


\section{BIBLIOGRAFIA}

BASTIDE, R. Le candomblé de Bahia:(rite nagô). Mouton, 1958.

BASTIDE, R. Les religions africaines au Brésil; Contribution à une sociologie des interpénétrations de civilisation. Paris: PUF, 1960.

BASTIDE, R. Immigration et métamorphose d'un dieu. Cahiers internationaux de sociologie, v. 20, p.45-60, 1956.

BAUDIN, N. Fétichisme et féticheurs. Séminaire des missions africaines: Bureaux des missions catholiques, 1884.

BERGAD, L. The comparative histories of slavery in Brazil, Cuba, and the United States. Cambridge University Press, 2007.

BOSMAN, W. Voyage de Guinée: contenant une description nouvelle \& très-exacte de cette côte où l'on trouve \& où l'on trafique l'or, les dents d'Elephant, \& les esclaves..., Chès Antoine Schouten, 1705.

BOUCHE, P. La côte des esclaves et le Dahomey: sept ans en Afrique Occidentale. E. PlonNourrit, 1885.

CAPONE, S. A busca da África no Candomblé. Rio de Janeiro: Pallas, 2004.

CARNEIRO, E. Religiões negras. Rio de Janeiro, Civilização Brasileira, 1936.

CARNEIRO, E. Candomblés da Bahia. Editora do Museu do Estado da Bahia, 1948.

CARNEIRO, M.L.T. O racismo na História do Brasil. 8. Ed. São Paulo: Ática, 2003.

CASTILlO, L. E. Bamboxê Obitikô e a expansão do culto aos orixás (século XIX): uma rede religiosa afroatlântica. Tempo, v. 22, n.39, p. 126-153, 2016.

CASTILLO, L. E. Entre a oralidade e a escrita: a etnografia nos candomblés da Bahia. Salvador: EDUFBA, 2010.

CASTILlO, L. E.; PARÉS, L. N. Marcelina da Silva e seu mundo: novos dados para uma historiografia do candomblé ketu. Afro-Ásia, v. 36, p. 111-151, 2007.

CORREA, N.F. Sob o signo da ameaça: conflito, poder e feitiço nas religiões afro-brasileiras. São Paulo, 1998, 302f - Tese (Doutorado em Antropologia) - Pontifícia Universidade Católica de São Paulo.

COUTO, E.S. Viver e morrer entre irmãos: as irmandades e ordens terceiras de Salvador-BA. Revista Brasileira de História das Religiões, v.6, n.18, p. 07-23, 2014.

DA COSTA LIMA, V. O Conceito de 'Nação' nos Candomblés da Bahia. Afro-Ásia, v.12, p.65-90, 1976.

DA SILVA, V. G. Neopentecostalismo e religiões afro-brasileiras: Significados do ataque aos 
símbolos da herança religiosa africana no Brasil contemporâneo. Mana, V.13, n1, p.207-236, 2007.

DE AZEVEDO, C. M. M. Onda negra, medo branco: o negro no imaginário das elites--século XIX. Annablume, 1987.

DE BARROS, J.F.P. O banquete do Rei--Olubajé. Pallas Editora, 2005.

DE CASTRO, Y. P. Falares africanos na Bahia: um vocabulário afro-brasileiro. Brasil: Topbooks, 2001.

DOPAMU, P. Exu, o inimigo invisível do homem. Um estudo comparativo entre Exu da religião Ioruba (Nagô) e o Demônio das tradições cristã e mulçumana. São Paulo: Editora Oduduwa Ltda, 1990.

FERREIRA DIAS, J. Fórmulas Religiosas entre os Yorùbás: Olódùmarè, Òrìșà, Àṣẹ, Orí e İpin. Lisboa, 2011, 174f. Dissertação (Mestrado em História e Cultura das Religiões) - Faculdade de Letras, Universidade de Lisboa.

FONSECA, E. J. Olubajé: música e ritual numa festa pública do candomblé Ketu-Nagô do Rio de Janeiro. Cadernos do Colóquio, v.4.n,1, p. 33-44, 2007.

HALL, S. Da diáspora: identidades e mediações culturais. Belo Horizonte: ed. UFMG; Brasília: Representação da UNESCO no Brasil, 2003.

HALLGREN, R. C. B. The good things in life: A study of the traditional religious culture of the Yoruba people, Lund Studies, 1989.

HUBERT, H.; MAUSS, M. Sacrifice: Its nature and functions. University of Chicago Press, 1981.

HUGHES, D. Human sacrifice in ancient Greece. Psychology Press, 1991.

KLEIN, H.; LUNA, F.V. Slavery in Brazil. Cambridge University Press, 2009.

LANDES, R. The city of women. UNM Press, 1947.

LANDES, R. A Cidade das Mulheres. Rio de Janeiro: Editora da UFRJ, 2002.

LANGER, J. Morte, Sacrifício Humano e Renascimento: Uma interpretação Iconográfica da Runestone Viking de Hammar I. Mirabilia: electronic journal of antiquity and middle ages, 3, p. 93-129, 2003.

LETOURNEAU, C. L'évolution religieuse dans les diverses races humaines. França: Vigot frères, 1898.

LEVI, J.A. Compromisso e solução: escravidão e as irmandades afro-brasileiras: origem e formação das confrarias religiosas no Brasil colonial (1552-1822). Alemanha: LIT Verlag Münster, 2006.

LÜHNING, A. Acabe com esse santo, Pedrito vem aí... - Mito e realidade da perseguição policial ao 
candomblé baiano entre 1920 e 1942. Revista Usp, v. 28, p. 194-220, 1996.

MACEDO, E. Orixás, caboclos e guias: deuses ou demônios?, Universal, 1988.

MACHADO, M.D.C. Política e religião: a participação dos evangélicos nas eleições. FGV Editora, 2006.

MACHADO, M.D.C.; BURITY, J.; ORO, A.P. Os votos de Deus: Evangélicos, política e eleições no Brasil. Recife: Massangana, 2006.

MANDARINO, A. C. S. (Não) deu na primeira página: macumba, loucura e criminalidade. Aracaju: Fundação Oviêdo Teixeira, 2007.

MATORY, J. L. Feminismo, nacionalismo, e a luta pelo significado do adé no Candomblé: ou, como Edison Carneiro e Ruth Landes inverteram o curso da história. Revista de Antropologia, v.51, n.1, p. 107-121.

MATORY, J. L. Black Atlantic Religion: Tradition, Transnationalism and Matriarchy in the Afro-Brazilian Candomblé. Princeton: Princeton University Press, 2005.

MAUSS, M. Ensaio Sobre a Dádiva. Lisboa: Edições 70, 1988.

NINA RODIGUES, R. As raças humanas e a responsabilidade penal no Brazil, 1894.

NINA RODIGUES, R. O Animismo Fetichista dos Negros da Bahia, 1900.

NINA RODIGUES, R. Os Africanos no Brasil, 1906.

OLIVA, A. Os africanos entre representações: viagens reveladoras, olhares imprecisos e a invenção da África no imaginário Ocidental. Em tempo de histórias, v.9, p.90-114, 2005.

OLIVA, A. As faces de Exu: representações européias acerca da cosmologia dos orixás na África Ocidental (Séculos XIX e XX), Revista Múltipla, n.18, p. 9-37, 2005.

OLIVEIRA, N. F. A repressão policial às religiões de matriz afro-brasileira durante o período do Estado Novo (1937-1945). Rio de Janeiro, 2015, 172f - Universidade Federal Fluminense

ORO, P. A. A discriminação contra as religiões afro-brasileiras: ontem e hoje. Ciênc. Let., n. 44, p. 301-318, 2008.

ORO, A. P.; STEIL, C. A. Globalização e religião. Vozes, 1997.

PARÉS, L. N.; CASTILlO, L. E. José Pedro Autran and the Return of Xangô. Religião \& Sociedade, v. 35, n.1, p. 13-43, 2015.

PARÉS, L. N. A formação do candomblé: história e ritual da nação jeje na Bahia. Campinas: Unicamp, 2006.

PEEL, J. D. Y. Religious encounter and the making of the Yoruba. Bloomington: Indiana University Press.

PRANDI, R. Exu, de mensageiro a diabo. Sincretismo católico e demonização do orixá 
Exu., Revista Usp, v.50, p.46-63, 2001.

RABElO, M. Os Percursos Da Comida No Candomblé De Salvador. Papeles de Trabajo, n. 11, p. 86-108, 2013.

REIS, J. J. Escravidão e invenção da liberdade: estudos sobre o negro no Brasil. Editora Brasiliense em co-edição com o Conselho Nacional de Desenvolvimento Científico e Tecnológico, 1988.

REIS, J. J. De escravo rico a liberto: a história do africano Manoel Joaquim Ricardo na Bahia oitocentista. Revista de História, v.174, p. 15-68, 2016.

REIS, J. J. Identidade e diversidade étnicas nas irmandades negras no tempo da escravidão. Tempo, v.2, n.3, p. 7-33, 1996.

SANTOS, R.C. Aráayé a je nbo: Um Estudo sobre a Comensalidade em um Terreiro Keto da Bahia., s.d. disponível em $<$ http://eventos.livera.com.br/trabalho/98-1021295_01_07_2015_00-1745 9971.PDF>.

SANTOS, J. E. D. Os nagô e a morte. Petrópolis: Vozes, 1976.

SEEBER-TEGETHOFF, M. Grenzgänger: Uma consideração dos entrelaçamentos entre terreiro e Antropologia. Revista Anthropológicas, v.18, n.2, p. 123-152, 2007.

SCHRITZMEYER, A. L. P. Sortilégio de saberes: curandeiros e juízes nos tribunais brasileiros (1900-1990). Ibccrim, 2004.

SILVEIRA, R. O candomblé da Barroquinha: processo de constituição do primeiro terreiro baiano de keto. Salvador: Edições Maianga, 2006.

SILVEIRA, R. Do calundu ao candomblé. Revista de História da Biblioteca Nacional. 6, sp, 2005.

SILVEIRA, R. O candomblé da Barroquinha: processo de constituição do primeiro terreiro baiano de keto, Salvador: Maionga, 2006.

SWEET, J. H. Recreating Africa: Culture, Kinship, and Religion in the African-Portuguese World, 1441-1770. Carolina do Norte: Univ. of North Carolina Press, 2003.

SOUZA Jr, V. C. D. O banquete sagrado: notas sobre os "de comer" em terreiros de candomblé. Salvador: Atalho, 2009.

TYLOR, E. B. Primitive culture: researches into the development of mythology, philosophy, religion, art, and custom. J. Murray, 1871.

WILKERSON, S. J. In search of the mountain of foam: Human sacrifice in eastern Mesoamerica. Ritual Human Sacrifice in Mesoamerica, p. 101-132, 1984. 